〈調 査 報 告〉

\title{
川崎市における地下水中の低沸点有機塩素化合物の調查結果
}

$\begin{array}{lrrrrr}\text { 吉 } & \text { サナエ* } & \text { 山 } & \text { 本 } & \text { 順 } & \text { 昭* } \\ \text { 櫻 } & \text { 木 } & \text { 進* } & \text { 横 } & \text { 田 } & \text { 覚** }\end{array}$

\section{Survey of Organic Chlorinated Compounds of Ground Waters in Kawasaki City}

\section{Sanae YOSHIKAWA*, Nobuaki YAMAMOTO*, Susumu SAKURAGI* and Satoru YOKOTA**}

* Kawasaki Municipal Research Institute for Environmental Protection, 20-2, Tajima, Kawasakiku, Kawasaki 210 Japan

* Envivonmental Protection Bureau Pollution Control Division, Water Pollution Division, Miyamoto 1, Kawasaki-ku, Kawasaki 210 Japan

\begin{abstract}
We conducted an investigation into the levels of organic chlorinated compounds such as Trichloroethylene (TCE) in 36 underground water wells in Kawasaki city.

A high level of TCE was detected sides of Tama river. Also, 1.1.1-Trichloroethane (MC) was detected in the Suge area. From the investigation, it was found that the concentration of MC was related to the ground water level. Therefore, we suspect that polluted matter has been buried the ground.
\end{abstract}

Key words : organic chlorinated compounds, wells

\section{1.はじめに}

トリクロロエチレン，テトラクロロエチレン等低沸 点有機塩素化合物による地下水污染が全国的規模で広 がっている。川崎市においては，昭和58年からこれら の物質による污染実態調査を行っている。今回，平成 元年 5 月と 11 月の 2 回にわたり市内の地下水調査を 行ったので報告する。さらに川崎市北部の菅（すげ） 地区に抢ける1.1.1-トリクロロエタンによる地下水污 染原因究明調査経過についても報告する。

\section{2. 実態調査}

\section{1 調疽方法}

採水地点：Fig. 1 に示す36井 (川崎区 4 井，幸区 5 井， 中原区 5 井，高津区 7 井，宮前区 2 井，多摩区 9 井，

\section{麻生区 4 井)}

測定項目：トリクロロエチレン(TCE)，テトラクロロ エチレン (PCE)，1.1.1-トリクロロエタン ( $\mathrm{MC})$ ，四 塩化炭素

測定方法; JIS K 0125 溶媒抽出一ガスクロマトグ ラフ法

\section{2 調查地点概況}

川崎市は北西から南東へ延長 $33 \mathrm{Km}$ にわたる細長い 地形である。西には標高 $30 \sim 110 \mathrm{~m}$ の多摩丘陵と, 東は 多摩川によって形成された沖積低地から成っている。 多摩川の低地は扇状地平野, 自然堤防帯平野, 三角州 平野の 3 つに区分される。地質系統は，大別すると第 3 紀と第 4 紀である。丘陵を構成する地層は海成層で ある第 3 紀鮮新世の上総層群で，多摩川低地を構成す る地層は第 4 紀世洪積世・沖積世の堆積物である。多

* 川崎市公害研究所 $\overline{\mathbf{T}} 210$ 川崎市川崎区田島町 20- 2

** 川崎市環境保全局公害部水質課 $\overline{\mathbf{T}} 210$ 川崎市川崎区宮本町 1 


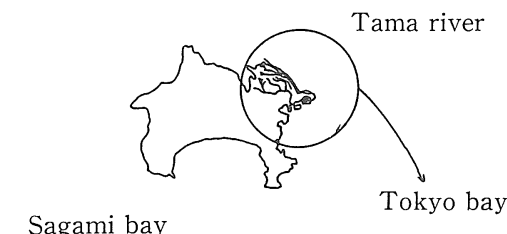

Sagami bay

Tokyo bay

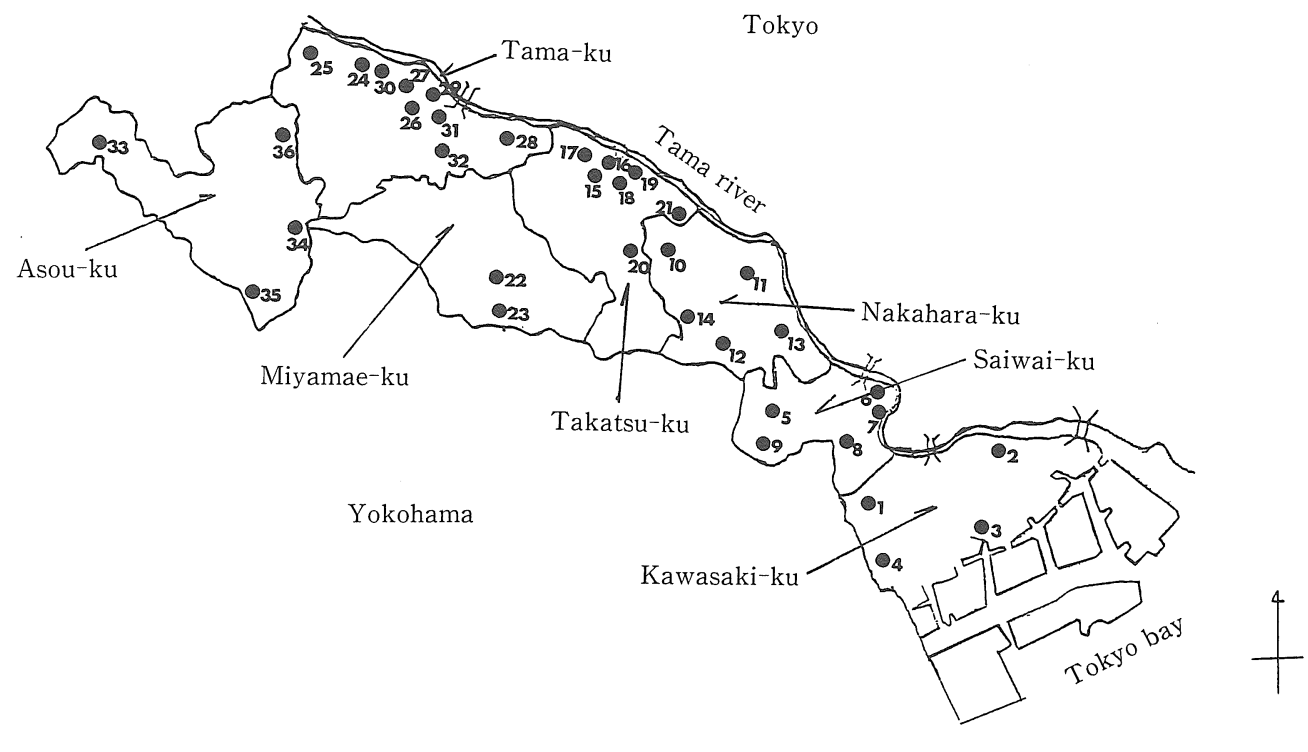

Fig. 1 Sampling Sites of Undergroundwater in Kawasaki City

摩川右岸の沖積層は砂れき主体で分布し，その層厚は $20 \mathrm{~m}$ 前後で自由地下水を含む帯水層である。上流域の 沖積層の地下水は循環性が高く，水質，水量ともに市 内では最も良好な帯水層となっている。

\section{3 調査結果}

2.3.1 月別 TCE, PCE, MC の平均值, 濃度範囲, 検出率

36井中の月別 TCE, PCE, MC の平均值, 濃度範囲, 検出率を Table 1 に示す。これより濃度を平均值で比 較すると 5 月, 11 月とも $\mathrm{TCE}>\mathrm{PCE}>\mathrm{MC}$ の順であっ た。また，各物質とも 5 月が 11 月より濃度が高かった。 検出率は 5 月は $\mathrm{TCE}>\mathrm{MC}>\mathrm{PCE}$ の順で，11月は $\mathrm{TCE}>\mathrm{PCE}>\mathrm{MC}$ の順であった。四塩化炭素はどの地 点からも検出されなかった。

\subsection{2 地区別 TCE 濃度}

11月における地区別 TCE 濃度を Fig. 2-A に示す。 これょり TCEの検出率は，高津区，多摩区が高く，高 濃度で検出されたのは幸区のNo.6地点と高津区の No. 15，16，17地点であった。No.6地点の経年変化を Fig. 3 に示す。これより昭和 58 年に $330 \mu \mathrm{g} ・ l^{-1}$ と最高 值を示し，その後減少傾向にあるが平成元年も $96 \mu \mathrm{g}$ 。
Table 1 Range of concentration and detected percentage of organic chlorinated compounds in undergroundwater

\begin{tabular}{|lccccc|}
\hline \multicolumn{1}{|l}{ Items } & $\mathrm{n}$ & $\begin{array}{c}\text { Mean } \\
\left(\mu \mathrm{g} \cdot l^{-1}\right)\end{array}$ & $\begin{array}{c}\mathrm{Max} \\
\left(\mu \mathrm{g} \cdot l^{-1}\right)\end{array}$ & $\begin{array}{c}\text { Min } \\
\left(\mu \mathrm{g} \cdot l^{-1}\right)\end{array}$ & $\begin{array}{c}\text { Detected } \\
\text { percentage } \\
(\%)\end{array}$ \\
\hline TCE & & & & & \\
$\quad$ May & 36 & 12 & 98 & $\mathrm{ND}$ & $42(15 / 36)$ \\
November & 36 & 11 & 96 & $\mathrm{ND}$ & $42(15 / 36)$ \\
PCE & & & & & \\
May & 36 & 2.6 & 44 & $\mathrm{ND}$ & $31(11 / 36)$ \\
November & 36 & 1.8 & 20 & $\mathrm{ND}$ & $25(9 / 36)$ \\
MC & & & & & \\
May & 36 & 2.5 & 29 & $\mathrm{ND}$ & $33(12 / 36)$ \\
November & 36 & 1.0 & 15 & $\mathrm{ND}$ & $22(8 / 36)$ \\
\hline
\end{tabular}

ND : None Detected

TCE $2 \mu \mathrm{g} \cdot l^{-1}, \mathrm{PCE} \quad 0.5 \mu \mathrm{g} \cdot l^{-1}, \mathrm{MC} \quad 0.5 \mu \mathrm{g} \cdot l^{-1}$

$l^{-1}$ で基準を超えていた。No.15，16，17の 3 地点は近 接しており付近一帯は，金属製品製造業の事業所が多 数立地している。この地点の経年変化を Fig. 4に示す。 これより No. 16 は昭和 58 年に最高值を示し，その值は 


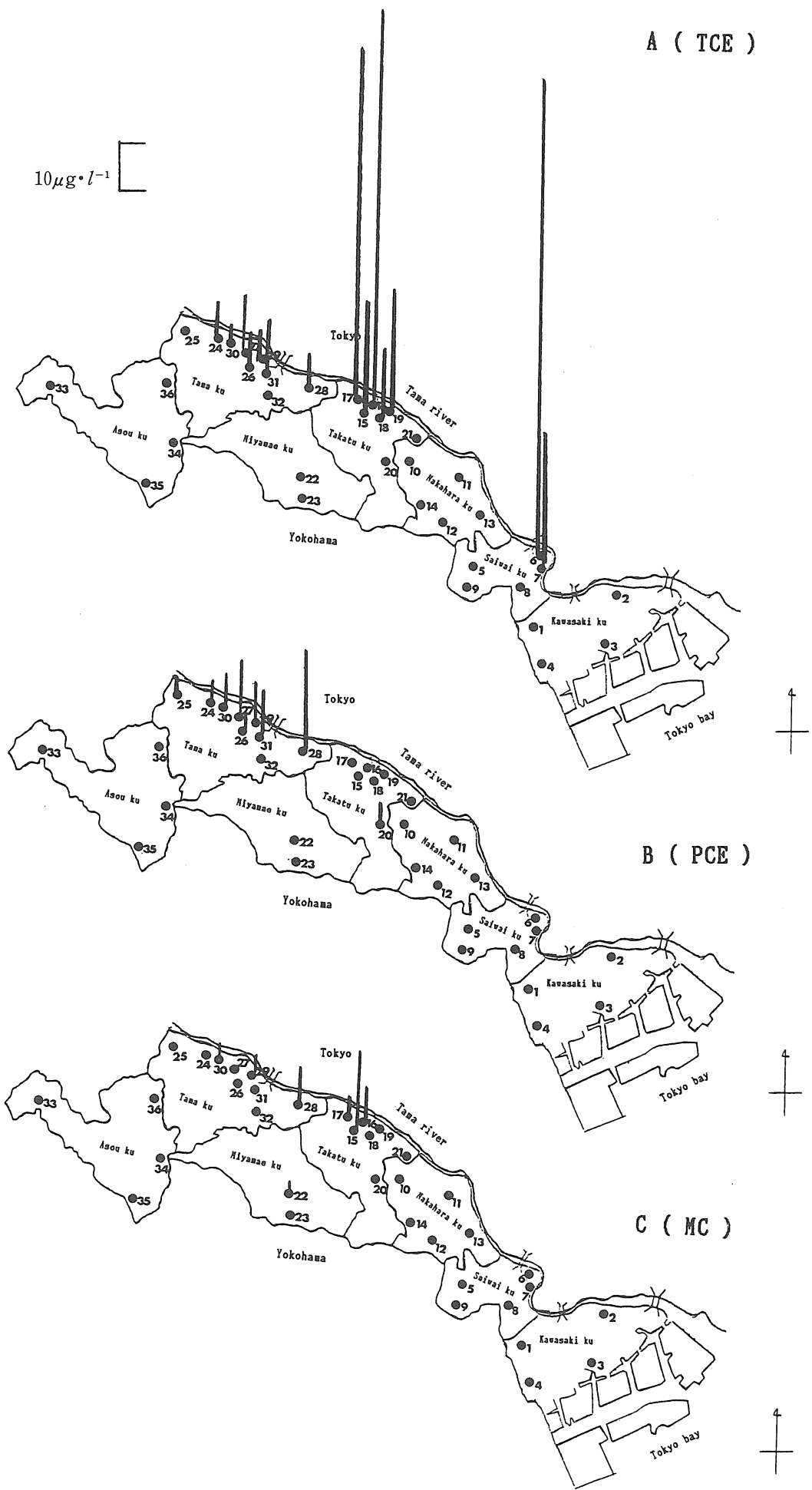

Fig. 2 Concentration of organic chlorinated compounds in undergroundwater 
$310 \mu \mathrm{g} \cdot l^{-1}$ であった。その後減少傾向にあるが平成元 年も $80 \mu \mathrm{g} \cdot l^{-1}$ で基準を超えていた。これら 2 地域につ いて現在詳細調査を実施中である。

また，Fig.3 と Fig.4 のパターンは非常に似通って いる。この地域は $13 \mathrm{Km}$ 程離れており共通しているも のは多摩川である。そこで多摩川の灌養について検討 するためモル百分率による放射線状グラフを作成し た。No.6地点, No.16地点と No.6地点付近の多摩川 の水について $\mathrm{Na}, \mathrm{K}, \mathrm{Ca}, \mathrm{Mg}, \mathrm{Cl}^{-}, \mathrm{SO}_{4}^{2-}, \mathrm{NO}_{3}^{-}$を 測定しパターンを比較した。その結果を Fig.5 に示 す。これよりNo.6地点, No.16地点は似たパターンで あったが多摩川は $\mathrm{Cl}$ の割合の大きい異なったパター ンを示し水脈が違うという事がわかった。

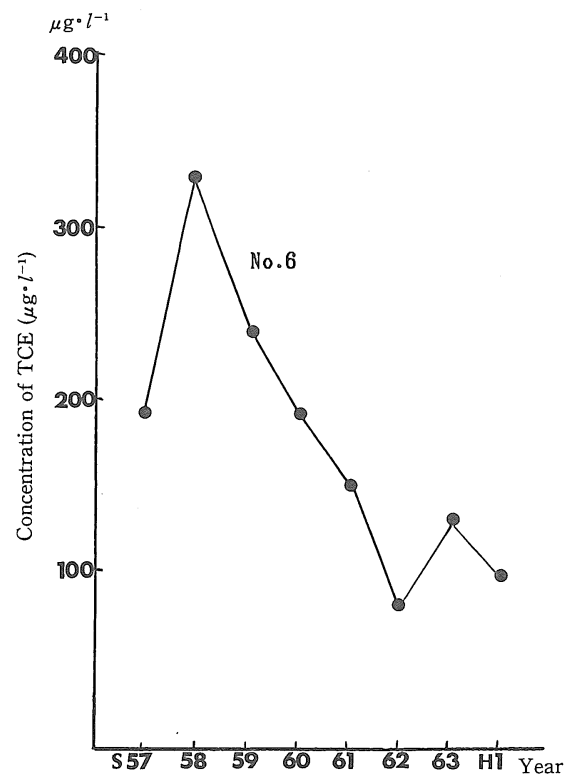

Fig. 3 Yerrly trend of pollution of TCE at No. 6

\subsection{3 地区別 PCE 濃度}

11月における地区別 PCE 濃度を Fig。 2-B に示す。 これらより PCEの検出率は, 多摩区が高く, 高濃度に 検出されたNo. 28地点では昭和 59 年に $250 \mu \mathrm{g} \cdot l^{-1}$, 昭 和62年に $320 \mu \mathrm{g} \cdot l^{-1}$ と高濃度を示し，その後は減少し ているが平成元年も $44 \mu \mathrm{g} \cdot l^{-1}$ で基準を超えていた。こ の原因としてNo.28に隣接するクリーニング店で PCE を含む活性炭処理後のドライクリーニング排水 の地下浸透が考えられた。このクリーニング店は昭和 63年に MC に変更している。

\subsection{4 地区別 MC 濃度}

11月における地区別 MC 濃度を Fig. 2-C に示す。 これより検出率は，高津区，多摩区が高いことがわか る。

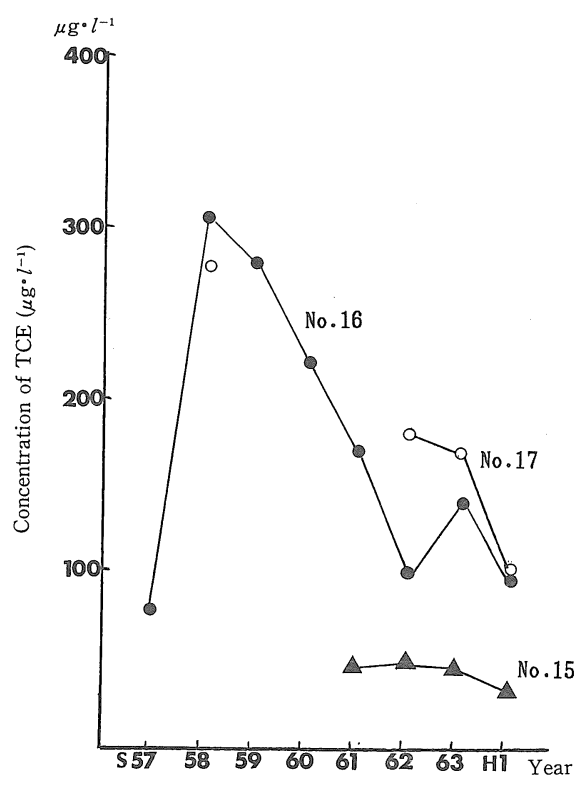

Fig. 4 Yerrly trend of pollution of TCE at No. 15, 16 and 17

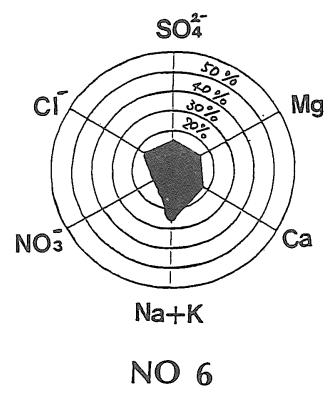

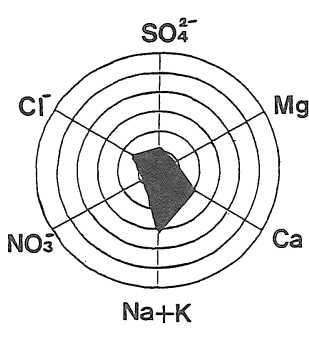

NO 16

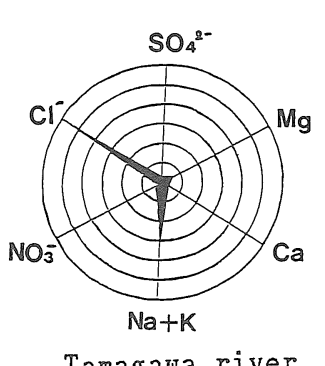

Tamagawa river

(Tamagawa ohhashi)

Fig.5 Radical graph by molar percentage at No. 6, 16 and Tama river 


\section{3 .5 各物質問の相関関係}

各物質間の関連性を検討するため 5 月，11月の地下 水計72検体について相関分析を行った。その結果，1\% 有意水準で有意性が認められたものはTCE と MCで 使用形態，挙動等が推測された。散布図を Fig.6 に示 す。

\section{3. 多摩区管地区におけるMCによる地下水污染源 究明調査}

\section{1 調查地点概況}

調査地点を Fig.7 に示す。菅地区の地質は沖積層 で，この地域で取水している地下水は不圧地下水（自 由地下水) である。地下水の主な流れは北西から南東 への流れである。

\section{2 調査経過}

平成元年 8 月 29 日：Fig. 7 に示す工業用水道水源の さく井No.1地点において MC 濃度 $350 \mu \mathrm{g} \cdot l^{-1}$ を検出した。

9 月 8 日：污染井戸周辺地区の工場・事業 場に打ける MCの使用状況調 査を行った。

9 月29日：菅地区一帯の地下水調査および $\mathrm{MC}$ 取り扱い工場の土壤調査を 行った。

\section{3 調査結果}

\section{3 .1 污染濃度と地下水位}

No. 1地点とその下流のある同じ工業用水道水源の
さく井 No. 2，No. 3地点の昭和63年 1 月〜平成 2 年 5 月までの MC 濃度の経月変化を Fig. 8 に，No. 1地点 の地下水位の経月変化を Fig.9 に示す。Fig. 8 より No. 1地点は昭和 63 年，平成元年とも 5 月に上昇を始 め，ピークは 9 月頃であった。その後減少し，平成 2 年 5 月には， $14 \mu \mathrm{g} \cdot l^{-1}$ で上昇傾向は見られない。No. 2，No. 3とも No. 1と同じような傾向を示し，No. 1， No. 2，No. 3の順に濃度は低くなっている。Fig.9よ り，地下水位は夏期に上昇し，濃度との関係を $\chi 2$ 検 定法で検討したところ $5 \%$ 有意水準で有意性が認めら

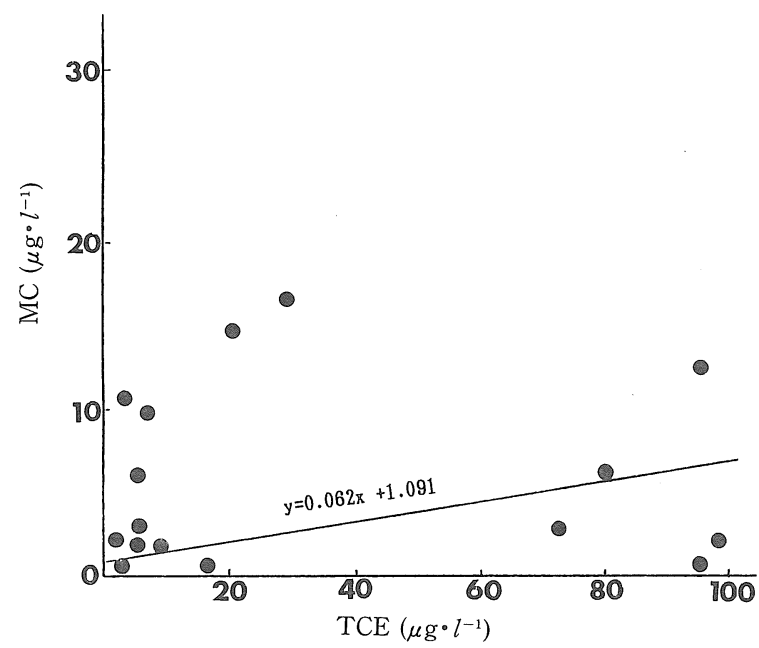

Fig.6 Relationship between TCE and MC

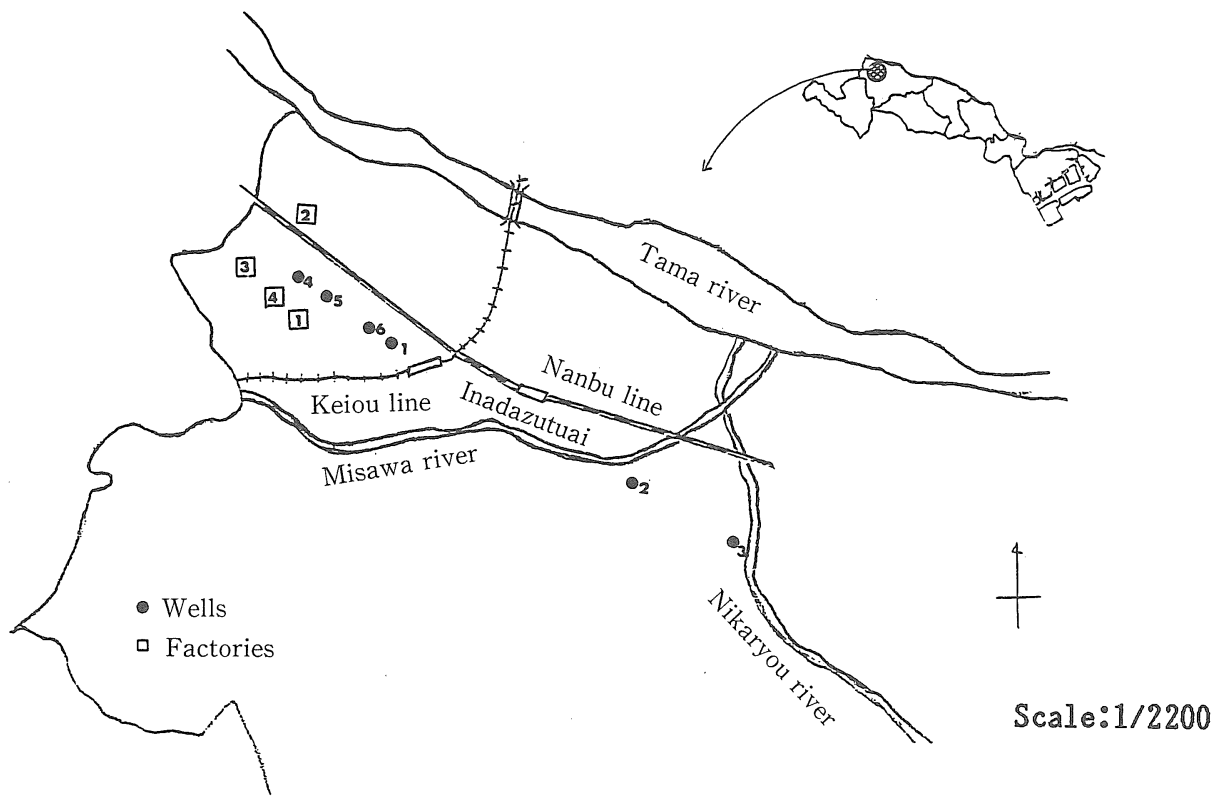

Fig. 7 Sampling sites at Suge area 


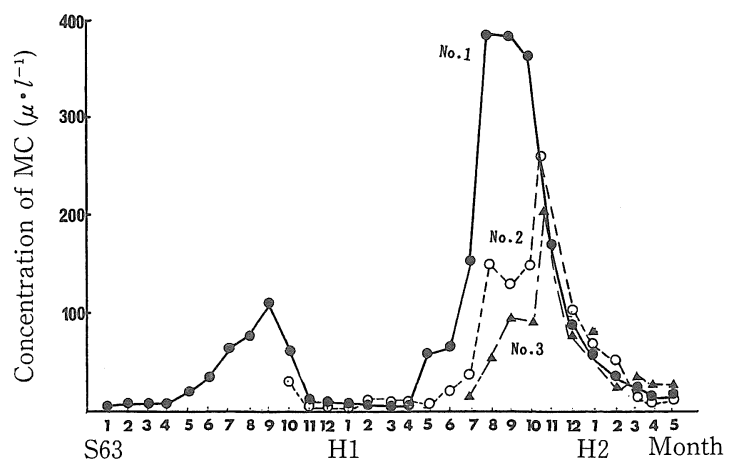

Fig. 8 Monthly trend of pollution of MC in wells at No. 1,2 and 3

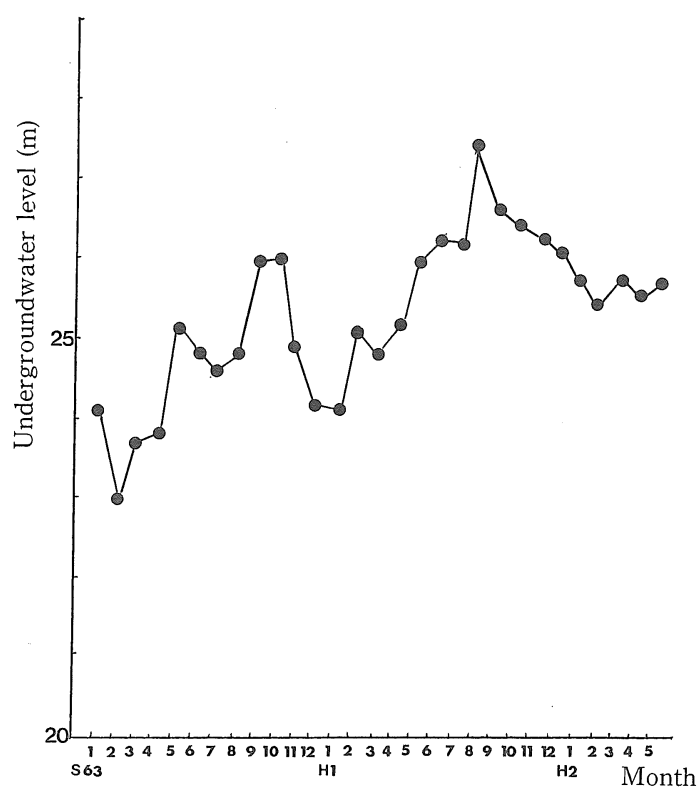

Fig.9 Monthly trend of undergroundwater levels at No. 1

れ，污染濃度と地下水位の間に関係がある事がわかっ た。

\section{3 .2 管地区一帯の地下水調査結果}

菅地区一帯の地下水調査を行った結果, Fig.7 に示 すNo. 4，5，6の 3 井が93〜 $470 \mu \mathrm{g} \cdot l^{-1}$ で高濃度であっ た。これら 3 井について継続調査を行った。その結果 を Fig. 10 に示す。これより平成元年には 3 井とも減 少傾向を示し，とくに，No.6はNo.1と同じ濃度パ ターンを示していた。また，No. 4，5，6の 3 井につい て一般水質項目を測定し2.3.2同様モル百分率による 放射線状グラフを作成した。その結果を Fig.11 に示 す。これより，この 3 井は同じ水脈である事が推測さ れた。

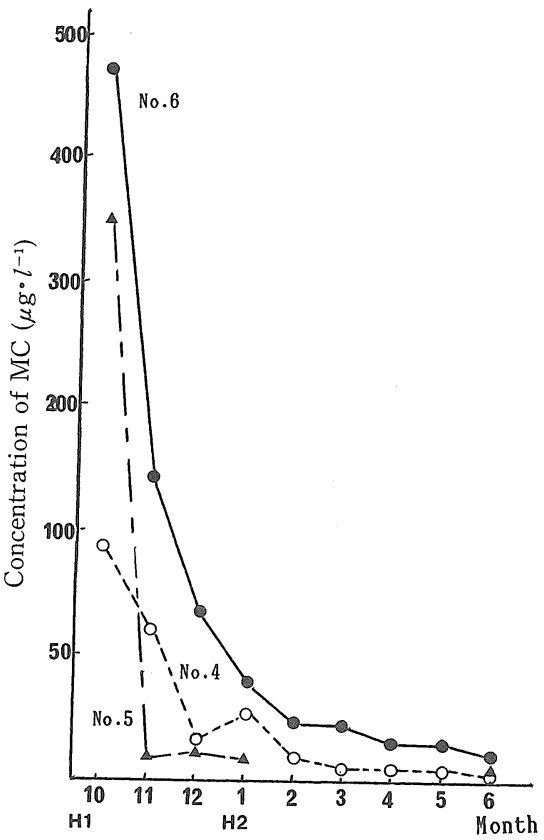

Fig. 10 Monthly trend of pollution of MC in wells at No. 4,5 and 6

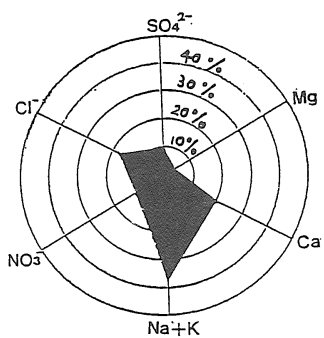

No. 4

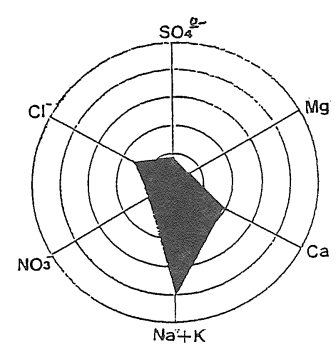

No. 5

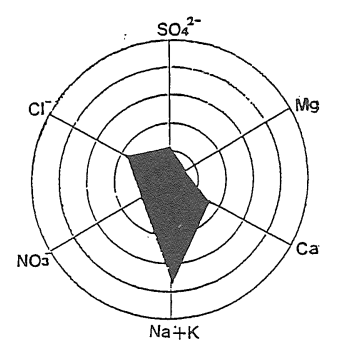

No.6

Fig. 11 Radical graph by molar percentage at No. 4,5 and 6 


\subsubsection{MC 取り扱い工場の土壤調査結果}

污染井戸周辺地区の工場・事業場29社における $\mathrm{MC}$ の使用状況調查を行った。その結果, 工場 No. 1，2， 3，4の 4 社において $\mathrm{MC}$ を使用していることがわかっ た。使用目的は 4 社とも脱脂洗浄で排出先は排気ダク 卜から大気, 自然蒸発であった。これら工場の土鲛調 查を行った。表層土, 地下 $30 \mathrm{~cm}$ 地下 $1 \mathrm{~m}$ までの土壤 を採取しへキサンによるすりつぶし抽出2)を行い測定 した。その結果を Table 2 に示す。これより，いずれの 工場も地下 $1 \mathrm{~m}$ の土㙥から $\mathrm{MC}$ は検出されなかっ た。

Table 2 Concentration of MC in soil of factories

\begin{tabular}{|l|cccc|}
\hline Factory No. & 1 & 2 & 3 & 4 \\
\hline Surface & ND & 190 & 56 & ND \\
$-30 \mathrm{~cm}$ & - & - & 12 & - \\
$-50 \mathrm{~cm}$ & - & ND & ND & - \\
$-100 \mathrm{~cm}$ & - & ND & - & - \\
\hline
\end{tabular}

ND: None Detected, MC $4 \mu \mathrm{g} \cdot \mathrm{kg}^{-1}$

\section{3 .4 考 案}

以上の調査の結果， $\mathrm{MC}$ による菅地区の地下水污染 はNo. 1，No.6 付近に高濃度污染源があり北西から南
東へ向かう地下水の流れにより污染が移動，拡散した ものと考えられる。また，污染濃度と地下水位に相関 が認められたことから当該地域に污染物質が埋設して いることが推測された。1回の工場の土壌調査結果か らは污染物質の継続的地下浸透があるかないかはわか らないため今後,さらにボーリングバーなどを用い検 討する予定である。

4.まとめ

川崎市内の地下水中の低沸点有機塩素化合物による 污染実態調査を行った。その結果, TCE が濃度, 検出 率とも高いことがわかった。また，各物質とも検出率 は北部の高津区，多摩区の多摩川沿いが高い傾向に あった。

$M C$ による菅地区の地下水污染源究明調査の結果, 污染物質の埋設が考えられたが，確定には至っていな w。

（原稿受付 1990年10月15日）

（原稿受理 1991年 8 月 8 日）

引用 文 献

1) 平成元年度地下水水質調査報告書, 平成 2 年 3 月, 川崎市。

2 ) 吉川サナエ, 山田健二郎, 永田正信 (1987)へキサン抽出一ガ スクロマトグラフ法による土壤, 底質中の低沸点有機塩素化合 物の分析法の検討, 水質污濁研究, 10, 196-200。 


\section{論 文 要 旨}

\section{二相式傔気性メンブレンリアクターにおけるメタン生成細菌の活性について}

油科 嘉則* 長谷川 潤*

* 千代田化工建設株式会社環境技術開発センター

〈水質污濁研究 Vol.14 No.12（1991） pp.859〜866〉

大豆タンパク加工排水を処理するパイロットスケールの固定床型酸発酵槽およびメタン発酵槽の間に分離膜 を設置した二相式嫌気性リアクターの各槽の担体に付着しているメタン生成細菌の活性を調査した。6 種類の 基質を使用したバイアルテストによりメタン生成比活性を求めた結果, SS 閉鎖系となる分離膜十酸発酵槽と膜 透過水を受容するメタン発酵槽の担体付着細菌について次のことがわかった。酸発酵槽の細菌は，ギ酸，酶酸， プロピオン酸, 酪酸よりもエタノール基質に対して高い比活性を示した。メタン発酵槽の細菌は, 文献の UASB グラニュールのバイアルテスト結果と比較して，同等かそれ以上の比活性を示した。本実験より，酸発酵槽か らのメタン生成はタンパク質，アミノ酸，エタノール分解経路が大きく寄与していること，メタン発酵槽のメ タン生成細菌は有機酸培養の UASB グラニュールと類似した共生関係を有する細菌群であることが考察され た。

\section{干潟底泥における脱窒量の測定法の比較}

伊藤 和男* 土山 秀樹* 山守 英朋* 浦野 久美子**

* 名古屋市公害研究所 * * 玉野総合コンサルタント

〈水質污濁研究 Vol.14 No.12（1991） pp.867〜875〉

アセチレン阻害法による底泥の脱窒活性の測定について，以下の 3 種の方法の比較検討を行った。

( I ) スラリー状の泥を $\mathrm{BOD}$ ふらんびんで培養生成した $\mathrm{N}_{2} \mathrm{O}$ 生成量, (II) 末攪乱の柱状コア試料をガラスカ ラムにつめ生成する $\mathrm{N}_{2} \mathrm{O}$ 量，(III) 野外においてガラス円筒で捕集された $\mathrm{N}_{2} \mathrm{O}$ 量，これら 3 種の測定值は， （ I ）：61〜 62，(II）：33〜39，(III）：47〜 $56 \mathrm{mgN}_{2} \cdot \mathrm{m}^{-2} \cdot \mathrm{d}^{-1}$ であった。スラリー状の泥の培養びん法による測定 值は，末攪乱試料の測定值の約 2 倍であった。

名古屋港河口域の柱状コア試料による $\mathrm{N}_{2} \mathrm{O}$ 生成量の垂直分布を，BOD ふらんびん培養法で測定した。

\section{川崎市における地下水中の低漂点有機塩絜化合物の調査結果}

吉川 サナエ* 山本 順昭* 櫻木 進* 横田 覚**

* 川崎市公害研究所 $* *$ 川崎市環境保全局公害部水質課

〈水質污濁研究 Vol.14 No.12（1991） pp.876〜882〉

トリクロロエチレン，テトラクロロエチレン等の低沸点有機塩素化合物による川崎市内の地下水污染の現況 
を平成元年の 5 月と11月に調査した。調査対象井戸は36井である。その結果，検出率は，トリクロロエチレン $42 \%$ ，テトラクロロエチレン25３1\%，1,1,1-トリクロロエタン22３3\%で，四塩化炭素はどの井戸からも検 出されなかった。水道水の暫定水質基準を超えたものは，トリクロロエチレン 4 地点，テトラクロロエチレン 2 地点であった。

また，菅地区における1,1,1-トリクロロエタンの污染源追跡調査の結果，污染物質の検出が地下水位に関係 していることから污染物質の埋設が考えられたが確定には至っていない。

\section{活性污泥を用いる迅速 BOD の測定法}

宮脇 美由貴* 古川 正道* 鎌田 栄二郎*

* 名古屋工業技術試験所

〈水質污濁研究 Vol. 14 No.12（1991） pp.883〜887〉

DO (溶存酸素) で飽和した活性污泥懸濁液の液面が外気と接触した状態で，ばっ気することなく懸濁液中の DO 濃度の減少を連続的に計測した場合，DO 濃度は直線的に減少する。検水（基質または有機污濁物を含む） を添加すると急激に減少した後, 安定し再び直線的な減少勾配を示す。DO 濃度の減少勾配が検水添加前と同じ になった時点で成立する平行線の間の DO 濃度の差が添加した基質濃度に比例することから，簡易，迅速に $\mathrm{BOD}$ (迅速 BOD) を求める方法である。検水採取量は $100 \mathrm{~m} l$ までとする。本法の測定時間は約 10 分である。本 法では, 活性污泥濃度は MLSS として $3,000 〜 5,000 \mathrm{mg} ・ l^{-1}$ の範囲で, 検水の迅速 BOD 測定に影響を与えない。 